\title{
Endothelin-1 Treatment Induces an Experimental Cerebral Malaria-Like Syndrome in C57BL/6 Mice Infected with Plasmodium berghei NK65
}

\author{
Yuri C. Martins, ${ }^{*}$ Brandi D. Freeman, ${ }^{*}$ Oscar B. Akide Ndunge, ${ }^{*}$ Louis M. Weiss, ${ }^{* \dagger}$ Herbert B. Tanowitz, ${ }^{* \dagger}$ and
} Mahalia S. Desruisseaux ${ }^{\star \dagger}$

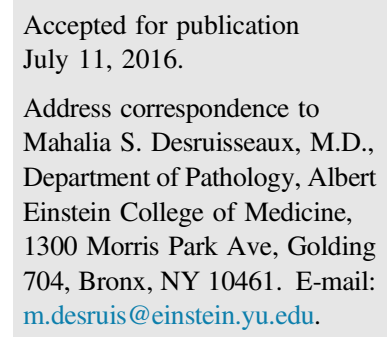

\begin{abstract}
Plasmodium berghei ANKA infection of $\mathrm{C} 57 \mathrm{BL} / 6$ mice is a widely used model of experimental cerebral malaria (ECM). By contrast, the nonneurotropic $P$. berghei $\mathrm{NK65}(\mathrm{PbN})$ causes severe malarial disease in C57BL/6 mice but does not cause ECM. Previous studies suggest that endothelin-1 (ET-1) contributes to the pathogenesis of ECM. In this study, we characterize the role of ET-1 on ECM vascular dysfunction. Mice infected with $10^{6} \mathrm{PbN}$-parasitized red blood cells were treated with either ET-1 or saline from 2 to 8 days postinfection (dpi). Plasmodium berghei ANKA-infected mice served as the positive control. ET-1treated $\mathrm{PbN}$-infected mice exhibited neurological signs, hypothermia, and behavioral alterations characteristic of ECM, dying 4 to 8 dpi. Parasitemia was not affected by ET-1 treatment. Saline-treated PbNinfected mice did not display ECM, surviving until 12 dpi. ET-1-treated PbN-infected mice displayed leukocyte adhesion to the vascular endothelia and petechial hemorrhages throughout the brain at $6 \mathrm{dpi}$. Intravital microscopic images demonstrated significant brain arteriolar vessel constriction, decreased functional capillary density, and increased blood-brain barrier permeability. These alterations were not present in either ET-1-treated uninfected or saline-treated $\mathrm{PbN}$-infected mice. In summary, ET-1 treatment of $\mathrm{PbN}$-infected mice induced an ECM-like syndrome, causing brain vasoconstriction, adherence of activated leukocytes in the cerebral microvasculature, and blood-brain barrier leakage, indicating that ET-1 is involved in the genesis of brain microvascular alterations that are the hallmark of ECM. (Am J Pathol 2016, 186: 2957-2969; http://dx.doi.org/10.1016/j.ajpath.2016.07.020)
\end{abstract}

Cerebral malaria (CM) is the deadliest complication of Plasmodium falciparum infection, with case fatality rates in clinical series varying from $8 \%$ to $19 \% .^{1}$ Brain vascular dysfunction is an important factor underlying CM pathophysiology, resulting in impaired cerebral blood flow, hemorrhage, hypoxia, blood-brain barrier (BBB) leakage, and, ultimately, coma and death. ${ }^{2,3}$ Vascular occlusion of the brain microvasculature by parasitized red blood cells (pRBCs), vasoconstriction, and BBB leakage are the three main components of $\mathrm{CM}$ vasculopathy ${ }^{4-6}$; however, the mediators and mechanisms that trigger these processes are not completely understood.

Experimental cerebral malaria (ECM) models mimic the main characteristics of human CM and have been useful in investigations of CM pathogenesis for $>20$ years. $^{7-10}$ The best studied ECM model is the infection of C57BL/6 (B6) mice with Plasmodium berghei ANKA (PbA), which induces a fatal neurological syndrome 5 to 12 days postinfection (dpi). ${ }^{11-14}$ The brain of ECM mice displays

\footnotetext{
Supported by NIH Interhemispheric Research/Training in Infectious Disease training grant D43-TW007129 (Y.C.M.); Geographic Medicine and Emerging Infections training grant T32-AI070117 (B.D.F.); NIH National Institute of Allergy and Infectious Diseases grants R01-AI076248 (H.B.T.) and R01-AI93220 (L.M.W.); NIH National Institute of Neurological Disorders and Stroke grant R01-NS0695771 (M.S.D.); the Burroughs-Wellcome Fund's Career Awards for Medical Scientists (M.S.D.); and the Einstein-Montefiore Institute for Clinical and Translational Research Career Development Award (M.S.D.). The funders had no role in study design, data collection and analysis, decision to publish, or preparation of the manuscript.

Disclosures: None declared.

Current address of Y.C.M., Department of Anesthesia, Critical Care and Pain Medicine, Massachusetts General Hospital, Boston, MA.
} 
vascular occlusion, mainly by adherent leukocytes, diffuse microhemorrhages, vasoconstriction, and $\mathrm{BBB}$ leakage. ${ }^{12,13,15,16}$ B6 mice infected with $P$. berghei NK65 $(\mathrm{PbN})$ do not develop neurological signs, die after 12 days postinfection, and are widely accepted as a control infection model for the B6-PbA model. ${ }^{17-19}$

Endothelin-1 (ET-1) is thought to contribute to the pathogenesis of human $\mathrm{CM}^{20,21}$ Our group recently demonstrated that ET-1 is involved in ECM vasculopathy ${ }^{13,14}$; however, there are still significant gaps in understanding how ET-1 modulates brain vascular physiology during malaria infection. ET-1 is a potent regulator of the vascular tone, with mitogenic, apoptotic, and immunomodulatory properties. ${ }^{22-24}$ It is synthesized by vascular endothelial cells throughout the body as well as by a variety of other cells, including leukocytes, fibroblasts, vascular smooth muscle cells, neurons, and astrocytes. ${ }^{25}$ ET-1 acts through two transmembrane G-protein-coupled receptors, endothelin receptor $\mathrm{A}^{26}$ and $\mathrm{B} .{ }^{27}$ Endothelin receptor $\mathrm{A}$ and $\mathrm{B}$ form homodimers and heterodimers that have synergetic or opposing effects, depending on tissue type and physiological situation, ${ }^{25}$ thus making it difficult to predict the effects of ET-1 during any pathological situation.

In the present study, we characterized the role of ET-1 on ECM vascular dysfunction by demonstrating that exogenous administration of ET-1 to a non-ECM murine model induces an ECM-like syndrome, causing brain vasoconstriction, adherence of activated leukocytes in the cerebral microvasculature, and BBB leakage. Our findings indicate that ET-1 is involved in the genesis of brain microvascular alterations, the hallmark of ECM during $\mathrm{PbA}$ infection.

\section{Materials and Methods}

\section{Ethics Statement}

All experimental protocols were performed in strict accordance with the recommendations in the Guide for the Care and Use of Laboratory Animals ${ }^{28}$ of the NIH, reviewed and approved by the Institutional Animal Care and Use Committee of the Albert Einstein College of Medicine (Bronx, NY).

\section{Parasitology and Experimental Design}

Four-week-old female B6 mice (Jackson Laboratories, Bar Harbor, ME) were infected, i.p., with $1 \times 10^{6} \mathrm{PbN}$ or $\mathrm{PbA}$ parasitized red blood cells in $100 \mu \mathrm{L}$ of phosphate-buffered saline. Mice infected with $\mathrm{PbN}$ and healthy uninfected mice were randomly assigned for daily i.p. treatment with either normal saline (NS) or ET-1 $(0.375 \mathrm{mg} / \mathrm{kg}$ diluted in $100 \mu \mathrm{L}$ NS; US Biological, Salem, MA), starting at 2 dpi and continued until 9 dpi. ET-1 dosing was based on a doseresponse experiment demonstrating that uninfected mice did not show signs of ECM or alterations in motor behavior during or after 9 days of daily treatments. Uninfected mice treated with $0.75 \mathrm{mg} / \mathrm{kg}$ developed neurological signs of a stroke-like syndrome (limb paralysis, ataxia, and circling) and died between 3 and 5 days of treatment. PbA-infected mice were used as an ECM-positive control in all experiments.

Mortality, parasitemia, behavior, rectal temperature, and weight were monitored daily after infection. Parasitemia was assessed by examining thin tail blood smears stained with modified Giemsa (Sigma-Aldrich, St. Louis, MO). The slides were examined under a light microscope (model CH30RF100; Olympus, Tokyo, Japan) at $\times 1000$ magnification with an oil immersion lens. Parasitemia was calculated by counting the number of pRBCs in at least 1000 RBCs. Development of ECM and clinical course of infection were assessed by a modified SmithKline Beecham, Harwell, Imperial College, Royal London Hospital, phenotype assessment, where six behavioral tests (transfer arousal, locomotor activity, tail elevation, wire maneuver, contact righting reflex, and righting in arena) were examined. ${ }^{29}$ The performance in each test was assessed for an observation period of 1 minute, and a composite motor behavior score was determined ranging from 0 to 23 , where 23 indicates maximum performance and 0 indicates complete impairment, often coma. Exploratory behavior was measured by the number of rears completed by the mice during exploration of the arena. Body temperature was monitored by using a laboratory scale (model C305; Ohaus Corp., Parsippany, NJ) and an Accorn Series Thermocouple thermometer with a mouse rectal probe (Oakton Instruments, Vernon Hills, IL), respectively.

\section{Histology}

Brains from all experimental groups were collected and processed for histology at 6 dpi. Mice were anesthetized (ketamine, $150 \mathrm{mg} / \mathrm{kg}$; xylazine, $10 \mathrm{mg} / \mathrm{kg}$ ) and perfused with $10 \mathrm{~mL}$ of saline using a syringe perfusion setup. Each brain was carefully collected immediately after perfusion and stored in $4 \%$ paraformaldehyde during 48 hours for fixation. Brains were cut in four coronal slices of 2 to $3 \mathrm{~mm}$ using a mouse brain blocker (David Kopf Instruments, Tujunga, CA). Each slice was embedded in paraffin, and sections (5 $\mu \mathrm{m}$ thick) were obtained at approximately $400-\mu \mathrm{m}$ intervals. Sections were mounted in glass slides (two sections per slide) and stained with hematoxylin-eosin. The histology slides were analyzed, and images were taken using a Nikon Microphot-FXA microscope system and a Nikon digital sight DS-5 M camera (Nikon Corp., Tokyo, Japan).

Quantification of brain histological alterations was performed by an experienced investigator (Y.C.M.) in a blinded manner. Semiquantitative methods for congestion and hemorrhage analysis were used. The hemorrhage score was based on a scale of 0 to 4 , as previously reported. ${ }^{30}$ Briefly, 0 indicates RBCs are not present or confined within the blood vessels; 1, one vessel with minimal 
extravasation of RBCs in one field at $\times 10$ magnification; 2 , greater than one vessel with minimal extravasation; 3 , one vessel with extensive extravasation; and 4 , greater than one vessel with extensive extravasation. The congestion score was performed to quantify the amount of leukocytes and $\mathrm{RBCs}$ retained in the brain vasculature after perfusion, and it was also based on a scale of 0 to 4 . Briefly, 0 indicates no cells present within the blood vessels; 1 , vessels presenting minimal amount of RBCs and endothelial adhered leukocytes, occluding $<10 \%$ of the vessel lumen; 2 , vessels with moderate obstruction (ie, $10 \%$ to $50 \%$ of occlusion of the vessel lumen); 3 , vessels with extensive obstruction, or 50\% to $90 \%$ occlusion; and 4 , vessels with a totally occluded lumen.

Preparation of RNA Samples and Quantitative Real-Time PCR As described elsewhere, total RNA was extracted from the cerebrum and reverse transcribed to cDNA. ${ }^{14}$ CXCL-8, chemokine ligand (CCL) 2, P-selectin, E-selectin, and vascular cell adhesion molecule-1 transcription levels were assessed by real-time RT-PCR using Sybr Premix Ex Taq (Takara Bio USA, Inc., Mountain View, CA). The following primers were used: $5^{\prime}$-TTACTGCAACAGAAAGGAAG-3' (forward) and 5'-GGTATTAACCTGTTAGTAATTG-3' (reverse) for CXCL-8; 5'-GAGTAGGCT-GGAGAGCTAAAGAG-3' (forward) and $5^{\prime}$-AGGTAGTG-GATGCATTAGTTCAG-3' (reverse) for CCL2; 5'-ATCTG-GACCGGAAAGACTGGA-3' (forward) and 5'-GATTCCTGGACACTTGATGGC-3' (reverse) for P-selectin; 5' 5 $^{\prime}$-TAGCAAGAAGCCCACGTGTTC-3' (forward) and 5'-CAAGCTAAAGCCCTCATTGCA-3' (reverse) for E-selectin; 5'ACTGATTATCCAAGTCTCTCC- $3^{\prime}$ (forward) and $5^{\prime}$-CCATCCACAGACTTTAATACC-3' (reverse) for vascular cell adhesion molecule-1; and 5'-AACTTTGGCATTGTG-GAAGG- $3^{\prime}$ (forward) and 5'-ACACATTGGGGGTAGGAACA-3' (reverse) for glyceraldehyde-3-phosphate dehydrogenase. mRNA values were normalized to those of glyceraldehyde-3-phosphate dehydrogenase.

\section{Cranial Window Surgery}

A closed cranial window model was used as previously described. ${ }^{31}$ Briefly, 2 hours before starting the surgical procedure, mice were treated s.c. with ampicillin $(6 \mathrm{mg} / \mathrm{kg})$, dexamethasone $(0.2 \mathrm{mg} / \mathrm{kg})$, and buprenorphine $(0.1 \mathrm{mg} / \mathrm{kg})$ to provide analgesia and prevent surgical site infection and brain swelling. Before beginning surgery, mice are anesthetized (ketamine, $150 \mathrm{mg} / \mathrm{kg}$; xylazine, $10 \mathrm{mg} / \mathrm{kg}$, i.p.) and, after shaving the head and cleansing with ethanol $70 \%$ and betadine, mice were placed on a stereotaxic frame and the head immobilized using ear bars. A sagittal incision in the skin over the head was made with sterilized surgical instruments, and 2\% lidocaine was applied on the periosteum, which was then retracted, exposing the skull. A 3- to 4-mm-diameter skull opening was made in the right parietal bone using an Ideal microdrill (CellPoint Scientific,
Gaithersburg, MD). Under a drop of NS, the craniotomy was lifted away from the skull with thin tip forceps and gelfoam (Pfizer Inc., Kalamazoo, MI) previously soaked in NS applied to the dura mater to stop any eventual small bleeding. The exposed area was covered with a 5-mm glass coverslip (Electron Microscopy Sciences, Hatfield, PA) secured with cyanocrylate-based glue (Loctite; Henkel Corp., Rocky Hill, CT) and dental acrylic (Lang Dental Manufacturing Co, Wheeling, IL). Carprofen and ampicillin were given daily for 3 to 5 days after recovery from surgery. Mice presenting signs of pain or discomfort after surgery were euthanized using a carbon dioxide chamber.

\section{ET-1 Measurement in Whole Blood}

Whole blood was collected in heparinized tubes by puncture of the retro-orbital venous plexus 24 hours after last injection of ET-1 or vehicle. Blood was immediately processed, mixing in an equal volume of a lysis buffer $(150 \mathrm{mmol} / \mathrm{L}$ sodium chloride, $50 \mathrm{mmol} / \mathrm{L}$ Tris, $\mathrm{pH} 7.5,1 \% \mathrm{NP}-40,1$ $\mathrm{mol} / \mathrm{L}$ sodium fluoride, $0.25 \mathrm{~mol} / \mathrm{L}$ sodium pyrophosphate, $4 \mathrm{mmol} / \mathrm{L}$ sodium orthovanadate, and $0.1 \mu \mathrm{g} / \mathrm{mL}$ okadaic acid). Posteriorly, samples were sonicated for 10 seconds, followed by centrifugation at $16,363 \times g$ for 30 minutes, and supernatant was aliquoted and stored at $-70^{\circ} \mathrm{C}$. ET-1 levels were then measured in the supernatant using an endothelin-1 microplate enzyme-linked immunosorbent assay, according to manufacturer's instructions (R\&D Systems, Minneapolis, MN). ET-1 levels were normalized by the amount of protein in each aliquot that was measured using a bicinchoninic acid assay, according to the manufacturer's instructions (ThermoFisher Scientific, Rockford, IL).

\section{Intravital Microscopy}

Intravital microscopy was performed as previously described. ${ }^{12}$ At 2 to 3 weeks after surgery, mice were lightly anesthetized with isoflurane (4\% for induction, $1 \%$ to $2 \%$ for maintenance), held on a stereotaxic frame, and then transferred to an intravital microscope stage (customized Olympus SZX12-M2Bio fluorescence system; Kramer Scientific, Amesbury, MA). A panoramic picture $(25 \times)$ of the vessels under the window was taken, a total of 6 to 10 pial vessels (five to eight venules and two to four arterioles) per mouse were randomly selected using a Kramer scientific air objective $(20 \times)$, and images or videos were captured with a camera (Optronics or Hamamatsu ORCA-FLASH 2.8, Hamamatsu City, Japan, respectively). Arterioles, venules, and capillaries were easily differentiated using previously published criteria. ${ }^{32}$ The next day, mice were inoculated and the intravital microscopy procedure was repeated on days 5 and 6 after infection.

Analyses were made offline using ImageJ (NIH, Bethesda, MD; http://imagej.nih.gov/ij). Vessel diameter was determined using the DIAMETER plug-in. ${ }^{33}$ 


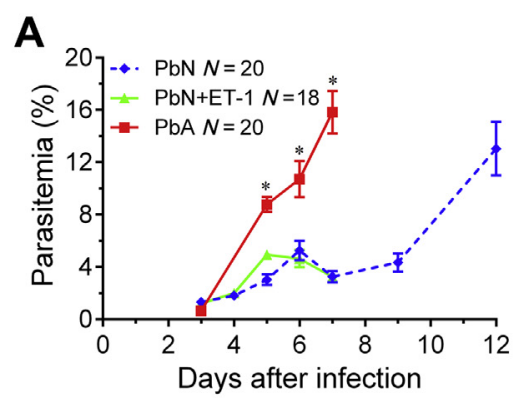

C

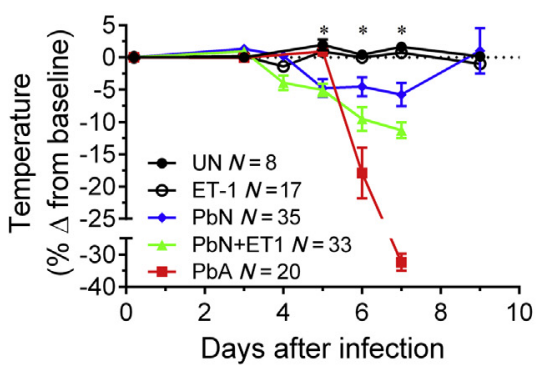

B

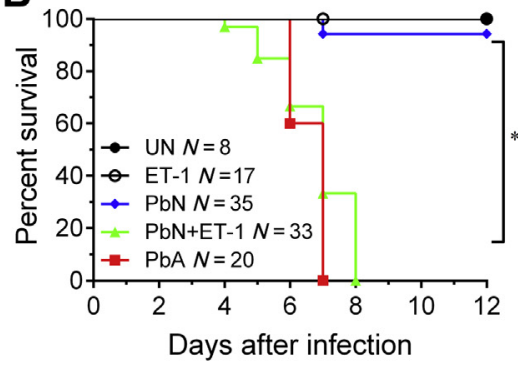

D

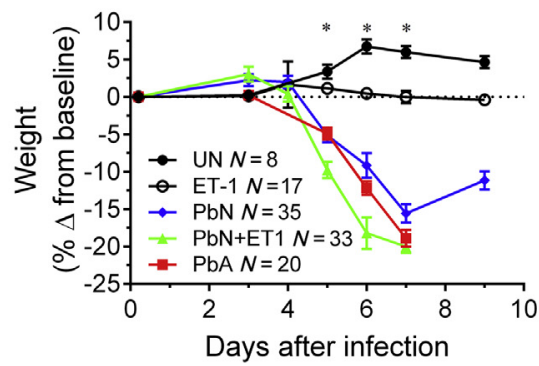

Figure 1 Disease progression in $\mathrm{PbN}$-infected mice treated with ET-1. A: Administration of exogenous ET-1 did not affect parasitemia in $\mathrm{PbN}$ infected mice (nonsignificant difference for $\mathrm{PbN}$ versus $\mathrm{PbN}+\mathrm{ET}-1$; significant difference for $\mathrm{PbA}$ versus $\mathrm{PbN}$ and $\mathrm{PbA}$ versus $\mathrm{PbN}+\mathrm{ET}-1)$. B: $\mathrm{ET}-1$ treatment significantly accelerated mortality in $\mathrm{PbN}$-infected mice [significant difference for the following comparisons: $\mathrm{PbA}$ versus $\mathrm{PbN}$; $\mathrm{PbA}$ versus ET-1 and vehicle-treated uninfected mice (UN); $\mathrm{PbN}$ versus $\mathrm{PbN}+\mathrm{ET}-1 ; \mathrm{PbN}+\mathrm{ET}-1$ versus $\mathrm{ET}-1$ and UN]. C: ET-1 treatment induced significant hypothermia (significant difference for the following comparisons: $\mathrm{PbA}$ versus $\mathrm{PbN}$; $\mathrm{PbA}$ versus $\mathrm{PbN}+\mathrm{ET}-1 ; \mathrm{PbA}$ versus ET-1 and $\mathrm{UN}$; PbN versus $\mathrm{PbN}+\mathrm{ET}-1 ; \mathrm{PbN}$ versus ET-1 and $\mathrm{UN} ; \mathrm{PbN}+\mathrm{ET}-1$ versus ET-1 and UN). D: ET-1 treatment also significantly worsened weight loss in $\mathrm{PbN}$-infected mice at 7 days postinfection (significant difference for the following: $\mathrm{PbA}$ versus $\mathrm{PbN}+\mathrm{ET}-1$; $\mathrm{PbA}$ versus $\mathrm{PbN}$; $\mathrm{PbA}$ versus $\mathrm{ET}-1$ and $\mathrm{UN}$; $\mathrm{PbN}$ versus $\mathrm{PbN}+\mathrm{ET}-1 ; \mathrm{PbN}$ versus ET-1 and $\mathrm{UN} ; \mathrm{PbN}+\mathrm{ET}-1$ versus $\mathrm{ET}-1$ and $\mathrm{UN}) .{ }^{*} P<0.05$.
Functional capillary density was determined immediately after i.v. administration of fluorescein isothiocyanate (FITC)-albumin (50 $\mu \mathrm{g}$ /mouse; Sigma, St. Louis, MO) by counting the total number of spontaneously perfused capillaries per square millimeter of surface area in random microscopic fields during 4 minutes. BBB permeability was determined 15 minutes after FITC-albumin injection. ${ }^{34}$ Briefly, we recorded a video image before the tracer was injected, and subtract this before image from all experimental images to eliminate any static background. A rectangular region of interest for a vessel (ROIv) with approximately $25 \times 60 \mu \mathrm{m}$ was chosen in the interior of a vessel and an analogous ROI for the surrounding tissue (ROIt) with the same size was chosen for comparison. The ROIt was selected approximately 5 to $10 \mu \mathrm{m}$ away from the vessel wall, with no additional surrounding vessels, no apparent underlying vessels, and homogeneous tissue intensity. The mean fluorescence intensity of each ROI was measured, and the extravasation (E) of the dye was represented by the following formula: $\mathrm{E}=\mathrm{ROIt} / \mathrm{ROIv}$.

\section{Evaluation of BBB Integrity with EBD}

In parallel experiments, mice were injected i.p. with $200 \mu \mathrm{L}$ of 2\% Evans Blue Dye (EBD; Sigma) at 6 dpi, and 2 hours later, the mice were anesthetized, perfused with ice cold saline, and euthanized for analysis of EBD concentration in the brain tissue. Brains were removed, weighed, and placed in formamide $\left(1 \mathrm{~mL}, 37^{\circ} \mathrm{C}\right)$ to extract EBD from the tissue. Absorbance was measured after 48 hours at $575 \mathrm{~nm}$. EBD concentration was calculated by using a standard curve.

\section{Statistical Analysis}

All statistical analyses were performed using Graphpad Prism 6.0 (San Diego, CA) or Stata 9.0 (StataCorp LP, College Station, TX). Experiments were replicated at least twice, with similar results obtained in each trial. Analyses were performed using either one-way analysis of variance or Kruskal-Wallis, with post hoc group comparisons tests. Survival curves were analyzed using the log-rank test. Changes were considered statistically significant if $P<0.05$.

\section{Results}

\section{ET-1 Treatment Causes Neurological Impairment and Death in PbN-Infected Mice}

To determine whether the exogenous administration of ET-1 would induce clinical ECM in PbN-infected $\mathrm{B} 6$ mice, we compared the survival, temperature, behavior, parasitemia, and weight of these mice to $\mathrm{PbN}$-infected mice injected with NS and PbA-infected mice. Although exogenous ET-1 administration to $\mathrm{PbN}$-infected mice had no antiparasitic effects (Figure 1A), treatment of $\mathrm{PbN}$-infected mice with ET-1 resulted in significantly reduced survival than $\mathrm{PbN}$ infected mice given NS (Figure 1B). A two-way analysis of variance revealed a synergistic interaction in the mortality effect caused by $\mathrm{PbN}$ infection and ET-1 treatment when combined $(P<0.001)$, indicating that the increase in mortality seen in $\mathrm{PbN}$-infected mice treated with ET-1 was not caused by simple addition of the toxic effects caused by both interventions. In fact, ET-1-treated $\mathrm{PbN}$ mice 
displayed similarly accelerated death rates to PbA-infected (ECM) mice. Treatment with ET-1 also induced hypothermia (Figure 1C) and weight loss (Figure 1D) in $\mathrm{PbN}$-infected mice.

Signs of ECM, such as ataxia, limb paralysis, seizures, and, rarely coma, were also observed in ET-1-treated $\mathrm{PbN}$ mice, in association with significantly worse behavior scores (Figure 2A) and exploratory behavior (Figure 2B) when compared to NS-treated $\mathrm{PbN}$-infected mice at 7 dpi. Uninfected mice treated with ET-1 neither lost weight nor displayed any significant changes in survival, behavior, and temperature compared to uninfected mice given NS.

Exogenous ET-1 administration in the dose and interval used increased blood ET-1 levels in uninfected and $\mathrm{PbN}$-infected mice to values similar to those found in $\mathrm{PbA}$ infected mice at 6 dpi (Figure 2C).

\section{ET-1 Treatment Results in Brain Hemorrhage and Microvascular Congestion in PbN-Infected Mice}

The hallmark of ECM is the presence of hemorrhages and vascular congestion caused by adherence of activated leukocytes to the endothelium in the brain. ${ }^{15,16}$ To determine whether PbN-infected B6 mice treated with ET-1 develop histopathological alterations characteristic of ECM, we analyzed the brain pathology of these mice at 6 dpi. $\mathrm{PbN}$-infected B6 mice treated with ET-1 presented with brain parenchymal hemorrhages and leukocytes adherent to the brain microvascular endothelium, at levels comparable to PbA-infected mice (Figure 3 and Table 1). However, the anatomical distribution of the vasculopathy differed between $\mathrm{PbA}$-infected mice and $\mathrm{PbN}$-infected mice treated with ET-1. Although hemorrhage and vascular congestion were uniformly distributed in all brain regions analyzed in $\mathrm{PbN}-$ infected mice treated with ET-1, these alterations occurred predominantly in the midbrain, pons, and cerebellum of $\mathrm{PbA}$ infected mice (Table 1). There were no alterations in brain pathology in uninfected mice treated with ET-1 when compared to uninfected mice treated with saline, indicating that, in the dose and scheme used, ET- 1 treatment alone did not induce histopathological alterations in the brain.

$\mathrm{CM}$ is associated leukocyte infiltration to the cerebral microvasculature ${ }^{35}$ has been strongly linked to neuronal damage and coma. ${ }^{35,36}$ Several chemokines important in monocyte recruitment and adhesion are increased with $\mathrm{CM}^{37}$ To determine the inflammatory mediators that are increased as a result of ET-1, we performed quantitative real-time PCR for CXCL-8 (Figure 4A), CCL2 (Figure 4B), and several cell adhesion molecules, including P-selectin (or CD62P) (Figure 4C), E-selectin (CD62E) (Figure 4D), and the vascular cell adhesion molecule 1 (or CD106) (Figure $4 \mathrm{E}$ ). $\mathrm{PbA}$ infection resulted in significantly higher levels of chemokines and cell adhesion molecules $(P<0.05)$ (Figure 4). However, exogenous administration of ET-1 only significantly increased mRNA levels of CXCL8 in PbN-infected mice $(P<0.01)$ (Figure 4A).
A

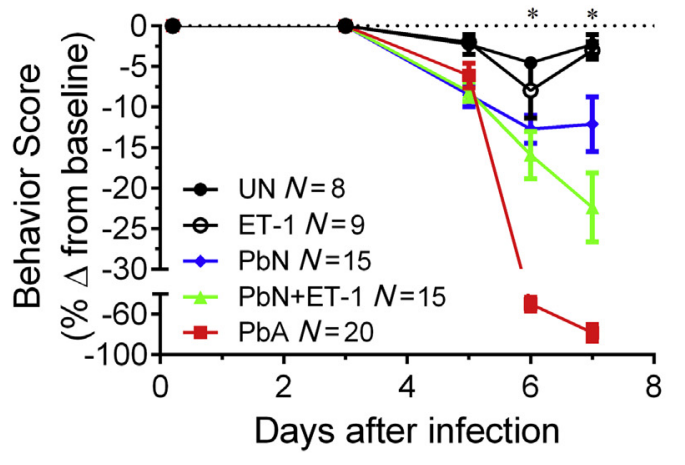

B
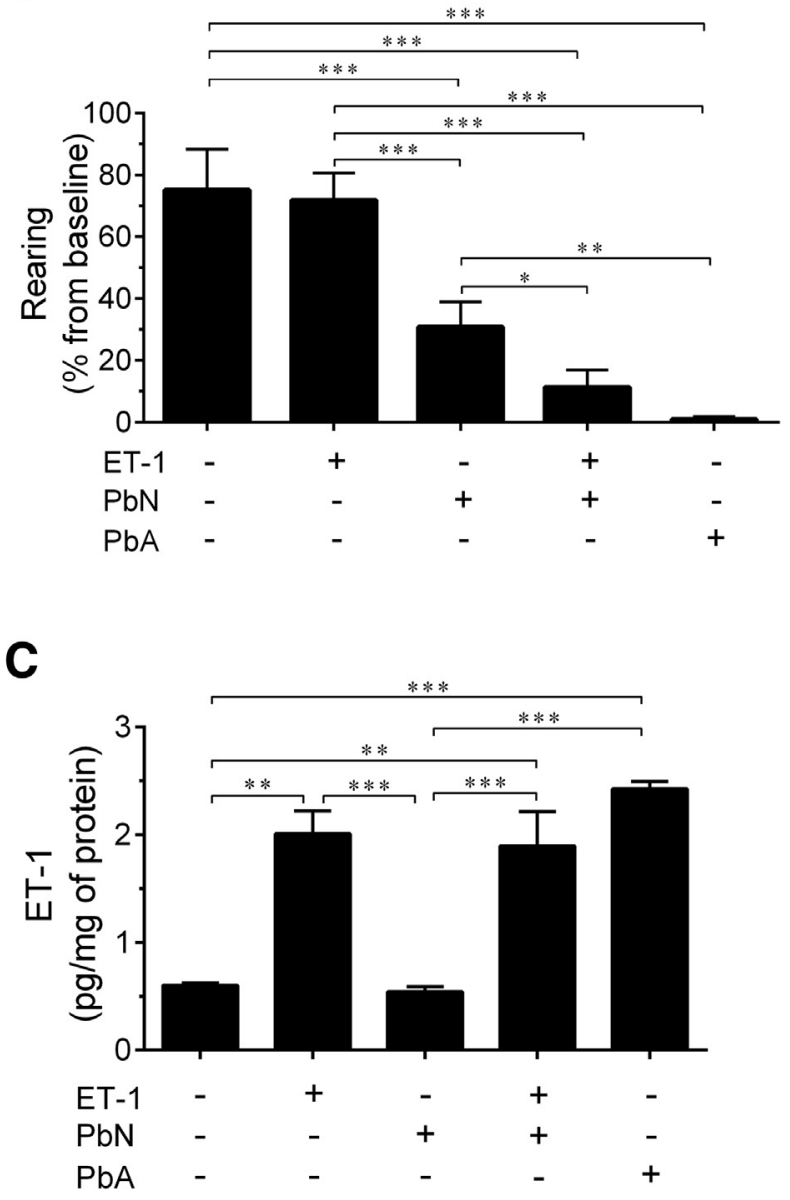

Figure 2 ET-1 effects on behavior scores in PbN-infected mice. A: ET-1 treatment significantly worsened the SmithKline Beecham, Harwell, Imperial College, Royal London Hospital, phenotype assessment behavior scores in $\mathrm{PbN}$-infected mice [significant difference for the following comparisons: $\mathrm{PbA}$ versus $\mathrm{PbN}+\mathrm{ET}-1$; $\mathrm{PbA}$ versus $\mathrm{PbN}$; $\mathrm{PbA}$ versus $\mathrm{ET}-1$ and vehicletreated uninfected mice (UN); $\mathrm{PbN}$ versus $\mathrm{PbN}+\mathrm{ET}-1 ; \mathrm{ET}-1$ and $\mathrm{UN}$ versus $\mathrm{PbA}, \mathrm{PbN}$, and $\mathrm{PbN}+\mathrm{ET}-1]$. B: In addition, $\mathrm{PbN}$-infected mice treated with ET-1 had significantly worse exploratory behavior than $\mathrm{PbN}$ infected mice treated with saline. C: Exogenous administration of ET-1 increased blood levels of ET-1 in uninfected and $\mathrm{PbN}$-infected mice even after 24 hours after bolus injection at 6 days postinfection. $N=7$ (B, UN, and C, ET-1); $N=9$ (B, ET-1, and C, PbN); $N=15$ (B, PbN and PbA); $N=$ $13(\mathbf{B}, \mathrm{PbN}+\mathrm{ET}-1) ; N=5(\mathbf{C}, \mathrm{UN}) ; N=10(\mathbf{C}, ; \mathrm{PbN}+\mathrm{ET}-1$ and $\mathrm{PbA})$. ${ }^{*} P<0.05,{ }^{* *} P<0.01$, and ${ }^{* *} P<0.001$. 

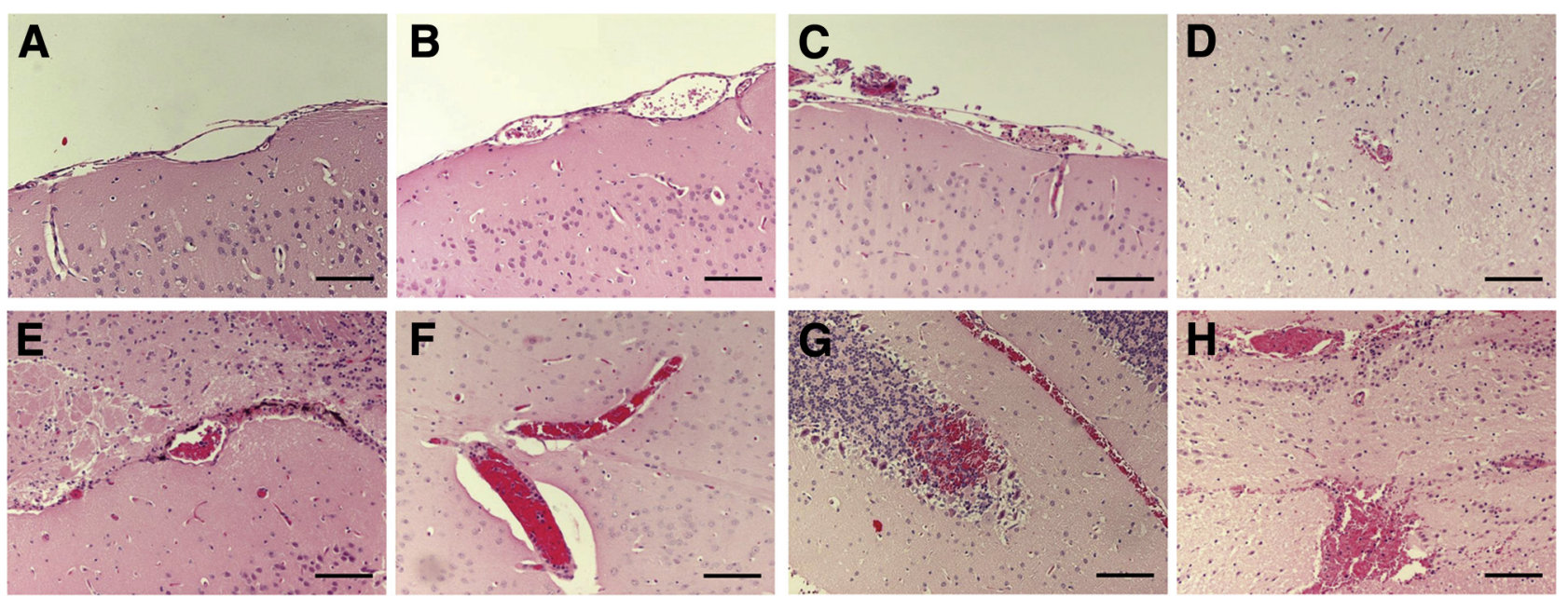

Figure 3 Brain pathology at 7 days postinfection. A: Vehicle-treated uninfected mice. B: Uninfected mice treated with ET-1. C and D: PbN-infected mice. E and F: PbN-infected mice treated with ET-1. G and $\mathbf{H}$ : PbA-infected mice. Hematoxylin and eosin staining was used. Scale bars $=100 \mu \mathrm{m}(\mathbf{A}-\mathbf{H}) .0$ riginal magnification, $\times 200(\mathbf{A}-\mathbf{H})$.

Furthermore, $\mathrm{PbN}$ infection induced significantly higher levels of CCL2 $(P<0.0001)$ (Figure 4B) and P-selectin $(P<0.01)$ (Figure $4 \mathrm{C})$ than uninfected control, albeit to lower levels than $\mathrm{PbA}$ infection $(P<0.0001)$ (Figure 4, B and C).

\section{ET-1 Treatment Causes Brain Arteriolar Constriction and Decreased Functional Capillary Density in PbN- Infected Mice}

The importance of brain arteriolar constriction in the development of ECM and its deleterious effects on disease severity cannot be overstated. Adjunctive treatment with the vasodilators nimodipine and glyceryl trinitrate improves survival in ECM mice. ${ }^{12,14,38,39}$ As ET-1 is a potent vasoconstrictor, $^{40}$ we used intravital microscopy in mice implanted with chronic cranial windows to analyze the brain microvascular changes caused by the ET-1 during experimental malarial infection. $\mathrm{PbA}$-infected mice and $\mathrm{PbN}$ infected ET-1-treated mice displayed significant degrees of brain arteriolar constriction at 5 and 6 dpi (Figure 5, A and B). In addition, decreased arteriolar diameter was significantly more pronounced at $6 \mathrm{dpi}$ than at $5 \mathrm{dpi}$ in both groups $(P<0.05)$. Interestingly, both uninfected mice treated with ET-1 and $\mathrm{PbN}$-infected mice treated with NS also displayed brain arteriolar constriction at $6 \mathrm{dpi}$. However, the degree of arteriolar constriction in those mice was significantly less than in $\mathrm{PbN}$-infected mice treated with ET-1 or PbA-infected mice (Figure 5B). Furthermore, the individual effect of each stimulus on brain vascular physiology was not sufficient to produce obvious clinical signs. A two-way analysis of variance revealed no interaction between $\mathrm{PbN}$ infection and ET-1 treatment at $6 \mathrm{dpi}$, indicating that both interventions acted independently in eliciting brain arteriolar constriction.
The significant degree of brain arteriolar constriction displayed by $\mathrm{PbA}$-infected mice and $\mathrm{PbN}$-infected mice treated with ET-1 strongly suggests a decrease in cerebral blood flow perfusion. Functional capillary density is a parameter used to determine tissue perfusion by intravital microscopy. ${ }^{41}$ The number of functional capillaries was significantly lower in all experimental groups when compared to uninfected control mice at 5 and 6 dpi (Figure 5,C and D). Functional capillary density in $\mathrm{PbN}$-infected mice treated with ET-1 was not significantly different from $\mathrm{PbN}$-infected mice at 5 dpi. However, $\mathrm{PbN}$-infected mice treated with ET-1 and PbA-infected mice displayed a significant reduction in the number of functional capillaries when compared to $\mathrm{PbN}$-infected mice or to uninfected mice treated with ET-1 at 6 dpi (Figure 5D). These data indicate that exogenous administration of ET- 1 causes brain arteriolar vasoconstriction with consequent decrease in the amount of functional capillaries in $\mathrm{PbN}$-infected mice.

ET-1 treatment did not induce any changes in venular diameter in uninfected control or $\mathrm{PbN}$-infected mice (Supplemental Figure S1).

\section{ET-1 Treatment Causes BBB Leakage in PbN-Infected Mice}

ET-1 is known to increase BBB permeability. ${ }^{42,43}$ To determine whether BBB leakage in ECM was caused by ET-1, BBB permeability was measured using intravital microscopy (Figure 6, A and B). PbN-infected mice treated with ET-1 had a significant increase in BBB permeability when compared to uninfected mice (with or without ET-1 treatment) or to $\mathrm{PbN}$-infected mice at 5 and $6 \mathrm{dpi}$ (Figure 6, A and B). The extravasation of FITC-conjugated albumin in the brain of $\mathrm{PbN}$-infected mice treated with ET-1 was significantly higher than in $\mathrm{PbA}$-infected mice at $5 \mathrm{dpi}$ (Figure 6A); however, although this leakage plateaued in the 
Table 1 Quantification of Histopathological Alterations in the Brain

\begin{tabular}{|c|c|c|c|c|c|}
\hline Brain region & $\mathrm{UN}(n=3)$ & $\mathrm{ET}-1(n=6)$ & $\mathrm{PbN}(n=15)$ & $\mathrm{PbN}+\mathrm{ET}-1(n=15)$ & $\mathrm{PbA}(n=5)$ \\
\hline \multicolumn{6}{|l|}{ Congestion score } \\
\hline Olfactory bulb & $0(0 / 0)$ & $0(0 / 0)$ & $0(0 / 0.75)$ & $1.5(0.25 / 2.75)^{* \dagger}$ & $4(3 / 4)^{* \dagger}$ \\
\hline Cortex & $0(0 / 0)$ & $0(0 / 0.25)$ & $1(0 / 1)^{*}$ & $2(1 / 3)^{* \dagger}$ & $2(2 / 2.5)^{* \dagger}$ \\
\hline Corpus callosum & $0(0 / 0)$ & $0(0 / 0)$ & $0(0 / 0)$ & $1(0 / 1)^{*}$ & $1(0 / 1)^{*}$ \\
\hline Hippocampus & $0(0 / 0)$ & $0.5(0 / 1.25)$ & $0(0 / 1)$ & $1(1 / 2.25)^{* \dagger}$ & $1(1 / 2.5)^{* \dagger}$ \\
\hline Thalamus & $0(0 / 1)$ & $0(0 / 1)$ & $0(0 / 1)$ & $2(1 / 4)^{* \dagger}$ & $2(1 / 2)^{* \dagger}$ \\
\hline Pons & $0(0 / 0)$ & $0(0 / 1)$ & $0(0 / 2)$ & $1(1 / 3)^{*}$ & $3(2 / 3.5)^{* \dagger}$ \\
\hline Cerebellum & $0(0 / 0)$ & $1(0 / 2)$ & $1(0 / 1)^{*}$ & $2(1 / 4)^{* \dagger}$ & $4(3 / 4)^{* \dagger}$ \\
\hline \multicolumn{6}{|l|}{ Hemorrhage score } \\
\hline Olfactory bulb & $0(0 / 0)$ & $0(0 / 0)$ & $1(0 / 1.75)^{*}$ & $2(0.25 / 2.75)^{*}$ & $4(3 / 4)^{* \dagger}$ \\
\hline Cortex & $0(0 / 0)$ & $0(0 / 1)$ & $0(0 / 2)$ & $1(0 / 2)^{*}$ & $2(1 / 2)^{*}$ \\
\hline Midbrain & $0(0 / 0)$ & $0(0 / 0.5)$ & $1(0 / 1.5)^{*}$ & $1(0.75 / 2.25)^{*}$ & $2(1.5 / 3)^{* \dagger}$ \\
\hline Pons & $0(0 / 0)$ & $0.5(0 / 2)$ & $1(0 / 1)^{*}$ & $2(1 / 3)^{* \dagger}$ & $2(1.5 / 3)^{* \dagger}$ \\
\hline Cerebellum & $0(0 / 0)$ & $0(0 / 1.25)$ & $2(0 / 2)^{*}$ & $3(1 / 3.5)^{*}$ & $4(3 / 4)^{* \dagger}$ \\
\hline
\end{tabular}

${ }^{*} P<0.05$ when compared to UN and ET-1.

${ }^{\dagger} P<0.05$ when compared to $\mathrm{PbN}$.

ET-1, uninfected mice treated with endothelin-1; PbA, Plasmodium berghei ANKA-infected mice; PbN, P. berghei NK65-infected mice; PbN + ET-1, PbNinfected mice treated with ET-1; UN, uninfected mice.

former group (Figure 6, A and B), it significantly increased in the brains of PbA-infected mice at 6 dpi (Figure 6B), indicating that BBB leakage peaked earlier in the brain of ET-1-treated $\mathrm{PbN}$-infected mice (Figure 6, A and $\mathrm{B}$ ). Although BBB permeability did not worsen in $\mathrm{PbN}$-infected mice treated with ET-1 at $6 \mathrm{dpi}$, uninfected mice treated with ET-1 and $\mathrm{PbN}$-infected mice also displayed a significant increase in BBB permeability when compared to uninfected mice at 6 dpi. To confirm these observations, BBB permeability was also determined by measuring EBD extravasation in the brain 6 dpi (Figure 6C). A two-way analysis of variance revealed a synergistic relationship between $\mathrm{PbN}$ infection and ET-1 treatment in Figure 6C, indicating that the increase in BBB permeability to EBD seen in the $\mathrm{PbN}+\mathrm{ET}-1$ group was not caused by an additive effect of both interventions.

The EBD leakage assay confirmed that PbA-infected mice and $\mathrm{PbN}$-infected mice treated with ET-1 had a markedly high degree of BBB permeability when compared to the other experimental groups. Interestingly, however, uninfected mice treated with ET-1 and PbN-infected mice did not exhibit an increase in extravasation for EBD-bound albumin, despite only a relatively small change in the molecular weight of the conjugated indicators [FITC-389 Da (National Center for Biotechnology Information, PubChem Compound Database; http://pubchem.ncbi.nlm.nih.gov; compound record CID18730) versus EBD-961 $\mathrm{Da}^{44}$ ], suggesting some degree of selective BBB permeability, unrelated to size, with the use of FITC-bound albumin in these mice. ${ }^{45,46}$ With either indicator, the administration of exogenous ET-1 to $\mathrm{PbN}$-infected mice and $\mathrm{PbA}$ infection both conferred significantly more BBB impairment than infection with $\mathrm{PbN}$ alone or treatment with ET-1 alone.

\section{Discussion}

Elevated levels of ET-1 have been implicated in the pathogenesis of both human and experimental CM. ${ }^{14,20,21,47}$ In the current study, we investigated the ability of ET-1 to induce an ECM-like phenotype in a mouse model that generally does not develop ECM. We examined behavioral, histopathologic, and cerebrovascular parameters in B6 mice infected with $\mathrm{PbN}$ and treated with exogenous ET-1 in comparison to $\mathrm{PbN}$-infected $\mathrm{B} 6$ mice given NS or to $\mathrm{PbA}$ infected mice. Exogenous ET-1 treatment accelerated mortality and triggered signs of ECM, including ataxia, limb paralysis, and seizures in $\mathrm{PbN}$-infected mice. In addition, our results indicate that ET-1 contributes to ECM pathogenesis by causing leukocyte adhesion in the brain endothelia, BBB disruption, and worsening brain vessel constriction during $P$. berghei infection.

ET-1 regulates BBB permeability and leukocyte infiltration in the brain microvasculature. ${ }^{48-50}$ In $\mathrm{PbN}$-infected mice, ET-1 increased BBB leakage to EBD-bound albumin as well as the incidence of brain hemorrhage and endothelial adherent leukocytes. FITC has been shown to significantly alter both the molecular charge and the migration of albumin, ${ }^{45}$ resulting in significantly higher extravasation of albumin than other detectors. ${ }^{46}$ Although 
A

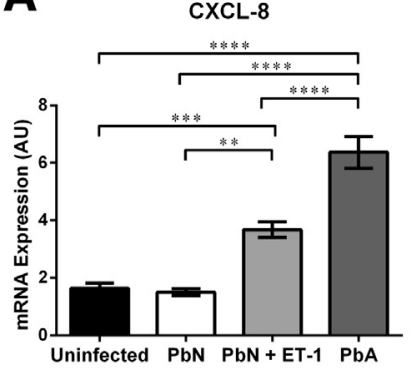

B

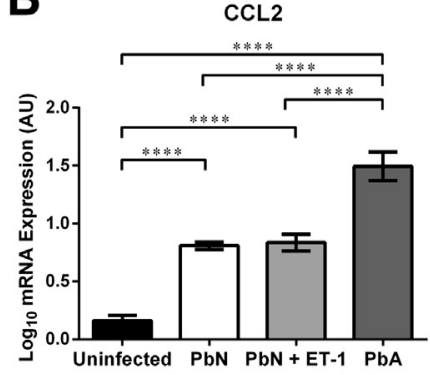

C

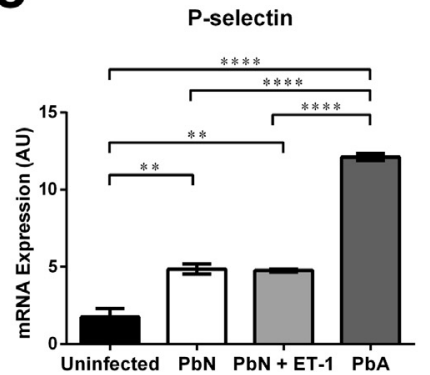

D

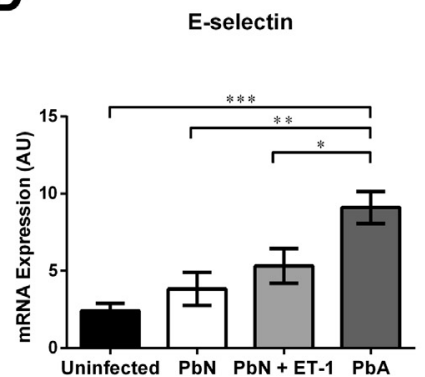

E

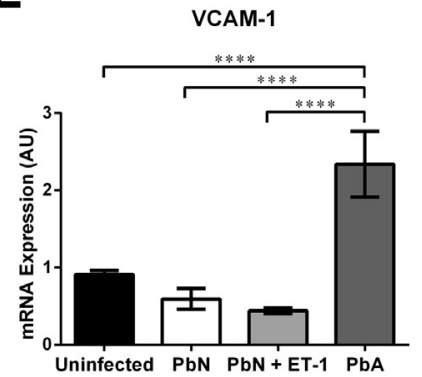

Figure 4 mRNA levels of chemokines and cell adhesion molecules in the brain at 7 days postinfection. A: PbN infection did not alter the transcription of CXCL-8 when compared to uninfected mice. However, when treated with exogenous ET-1, PbN-infected mice expressed significantly higher message levels of $\mathrm{CXCL}-8$ in the brain than $\mathrm{PbN}$-infected mice treated with saline or uninfected mice; the levels did not reach those observed during $\mathrm{PbA}$ infection. B: Both $\mathrm{PbA}$ and $\mathrm{PbN}$ infection resulted in higher mRNA levels of chemokine ligand (CCL) 2 than uninfected controls; however, $\mathrm{PbA}$-infected mice had significantly higher levels of the gene in the brain than PbN-infected mice. ET-1 treatment did not affect the transcription of CCL2 in PbN-infected mice. C: Similarly, both PbA and PbN infection resulted in higher levels of the cell adhesion molecule P-selectin, with $\mathrm{PbA}$-infected mice expressing significantly higher P-selectin levels than PbN-infected mice. ET-1 treatment did not alter the transcription of P-selectin in $\mathrm{PbN}$-infected mice. D and E: Mice infected with $\mathrm{PbA}$ displayed significantly higher levels of E-selectin (D) and vascular cell adhesion molecule (VCAM)-1 (E) than uninfected or PbN-infected mice. Neither PbN infection nor the treatment of PbN-infected mice with ET-1 had any effect on the expression of E-selectin or of VCAM-1 when compared to uninfected mice. For these analyses, ET-1 treatment of uninfected mice did not alter the mean expression of the genes analyzed; thus, uninfected mice treated with saline and uninfected mice treated with ET-1 were grouped. $N=10$ uninfected; $N=4-5 \mathrm{PbN}$ and $\mathrm{PbN}+\mathrm{ET}-1 ; N=4 \mathrm{PbA} .{ }^{*} P<0.05,{ }^{*} P<0.01,{ }^{*} * P<0.001$, and ${ }^{* * * * P}<0.0001 . \mathrm{AU}$, arbitrary unit.

this suggests that the presence, in our study, of increased FITC-bound albumin in the brains of PbN-infected mice or in the mice treated with exogenous ET-1 may be because of an inherent drawback of using FITC-albumin to detect BBB permeability, we cannot rule out the possibility that FITCalbumin may be a more sensitive agent, and that mild BBB leakage could occur during $\mathrm{PbN}$ infection or after administration of ET-1. Thus, we herein demonstrated that, although each individual insult $(\mathrm{PbN}$ infection or ET-1 treatment) may result in BBB damage when used alone, this damage was not sufficient to cause neurological symptoms, ECM-like pathology, or death. The cumulative damage in $\mathrm{PbN}$-infected mice treated with ET-1, which resulted in severe BBB leakage, induced an ECM-like illness that was similar to that caused by $\mathrm{PbA}$ infection.

We observed differences in the distribution patterns of hemorrhage and vascular congestion in the $\mathrm{PbN}$ mice treated with ET-1 compared to mice infected with $\mathrm{PbA}$. Likewise, in pathological studies of human CM, there is variability in the distribution of brain hemorrhage, from the presence of ring hemorrhages closely associated with occluded vessels in distinct brain regions, ${ }^{35}$ as observed in our $\mathrm{PbA}$ model, to diffuse, scattered patterns of petechial hemorrhages and leukocyte adhesion throughout the brain, ${ }^{51}$ as was seen in our ET-1-treated PbN model. In addition, parasitized red blood cell sequestration (pRBC) in pediatric $\mathrm{CM}$ is extensive, occurring in all parts of the brain, with substantial variability between individuals and between vessels in an individual with human cerebral malaria. ${ }^{6,34,52,53}$ Our data suggest a similar degree of variability of pathology between $\mathrm{PbA}$-infected and $\mathrm{PbN}$-infected mice, treated with exogenous ET-1.

Using intravital microscopy, we demonstrated that ET-1 treatment induced brain arteriolar constriction and consequently decreased functional capillary density in $\mathrm{PbN}$ infected mice. These vascular alterations were comparable to $\mathrm{PbA}$ infection induced $\mathrm{ECM}$, and significantly differed from $\mathrm{PbN}$-infected mice treated with NS. Although both uninfected mice treated with ET-1 and PbN-infected mice treated with NS also displayed a decrease in functional capillary density, the individual effect of each stimulus on brain vascular physiology was not sufficient to produce 
A

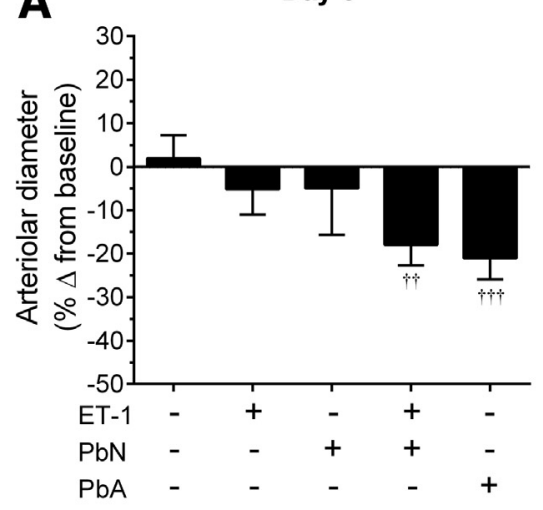

C

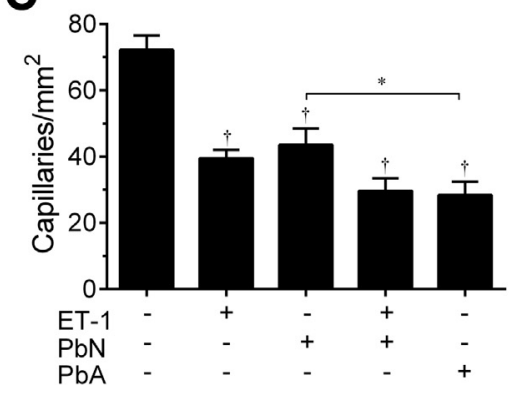

B

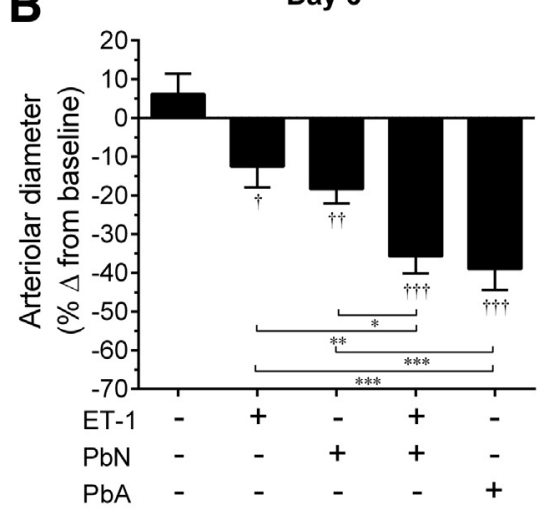

D

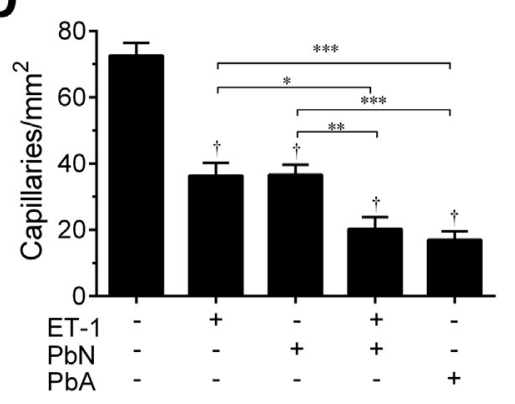

Figure 5 ET-1 increased arteriolar constriction and reduced functional capillary density in $\mathrm{PbN}$ infected mice. Brain intravital microscopy was performed to assess vessel patency and functional capillary density. A: At 5 days postinfection (dpi), both $\mathrm{PbA}$-infected mice and $\mathrm{PbN}$-infected mice treated with ET-1 displayed significantly narrower vessels than their preinfection baseline, whereas all other treatment groups had no change in their vessel diameter. B: At $6 \mathrm{dpi}$, all infected mouse groups, and ET-1-treated uninfected mice had a significant decrease in their vessel diameter from baseline. In $\mathrm{PbA}$-infected mice and in $\mathrm{PbN}$ infected mice treated with ET-1, this decrease was significantly more pronounced. ET-1 treatment induced a significantly greater vessel narrowing than $\mathrm{PbN}$-infected mice given normal saline or uninfected mice treated with ET-1. C and D: All infected mice and uninfected mice treated with ET-1 had significantly lower functional capillary density than uninfected control mice given saline, at 5 and $6 \mathrm{dpi}$; however, PbA infection resulted in significantly more pronounced reduction in functional capillary density than $\mathrm{PbN}$ infection on both days. D: At $6 \mathrm{dpi}$, ET-1 treatment significantly reduced the number of functional capillaries in $\mathrm{PbN}$-infected mice. ${ }^{*} P<0.05$, $* * P<0.01$, and $* * * P<0.001$ when comparing groups; ${ }^{\dagger} P<0.05,{ }^{\dagger \dagger} P<0.01$, and ${ }^{\dagger \dagger \dagger} P<0.001$ relative to baseline measurements. obvious clinical signs. Only when in combination (ie, infection and ET-1 treatment) did those stimuli result in large enough vasoconstriction to cause symptoms. Our findings support the notion that ET-1 participates in the development of both human ${ }^{20,21}$ and experimental ${ }^{13,14} \mathrm{CM}$. Elevated levels of ET-1 have been detected in the serum of patients with complicated $P$. falciparum infection. ${ }^{20,21}$ In mice with ECM, significant increases in brain ET-1, its receptors, and the endothelin-converting enzyme have been reported in association with a near 50\% reduction in cerebral blood flow. ${ }^{14}$

The ET system is widely distributed throughout the central nervous system and mediates a variety of physiological processes involved in various brain disorders. Intraventricular injection of ET-1 results in behavioral changes, including barrel rolling, body tilting, nystagmus, and tail extension. ${ }^{54}$ In addition, levels of ET-1 negatively correlate with mental status in patients with Alzheimer disease and multi-infarct dementia. ${ }^{55,56}$ In this regard, ET receptor antagonism improves neurological outcome in animal models of stroke and Alzheimer disease. ${ }^{57,58}$ Thus, our observation that ET-1 treatment induced neurological impairments in $\mathrm{PbN}$-infected mice was not surprising. The present study corroborates the potential use of ET-1 as a therapeutic target in patients with CM.

ET-1 regulates several pathogenic processes involved in CM. For example, ET-1 mediates BBB disruption and vasoconstriction. After middle cerebral artery occlusion, transgenic mice overexpressing endothelial ET-1 display increased BBB leakage. ${ }^{43}$ Furthermore, administration of ET-1 directly into the brain serves as a model for ischemic stroke in rodents. ${ }^{59}$ In this regard, intracisternal administration of ET-1 reduces cerebral blood flow and enhances BBB permeability, resulting in ischemic damage. ${ }^{59}$ Patel et $\mathrm{al}^{60}$ and Matsuo et $\mathrm{al}^{61}$ demonstrated that these cerebrovascular alterations occur via activation of the endothelin receptor A.

Similar to ischemic hypoxia, disruption of the cerebral vasculature is a key feature in the pathogenesis of CM. In both human and experimental CM studies, infection has been associated with a reduction in CBF, vasospasms, decreased or absent perfusion in the retinal vessels, breakdown of the BBB, and ischemia, ${ }^{2,4-6,12}$ alterations that coincide with adverse neurological sequelae and highlight the importance of vascular dysfunction in CM.

ET-1 has proinflammatory properties and is synthesized by a variety of cells, including vascular endothelial cells and leukocytes. ET-1 has been shown to regulate leukocyte trafficking and cytokine production. It stimulates the secretion of CXCL-8 and CCL2 in monocytes and even activates mast cell degranulation. Thus, it is likely that ET-1 during $\mathrm{CM}$ induces the up-regulation of these leukocyte binding molecules contributing to brain microvascular obstruction and pRBC sequestration. In this study, we demonstrated that ET-1 administration significantly induced the transcription of CXCL-8 in PbN-infected mice, and that this was associated with marked induction of brain microvascular obstruction by infiltrating leukocytes in 
A

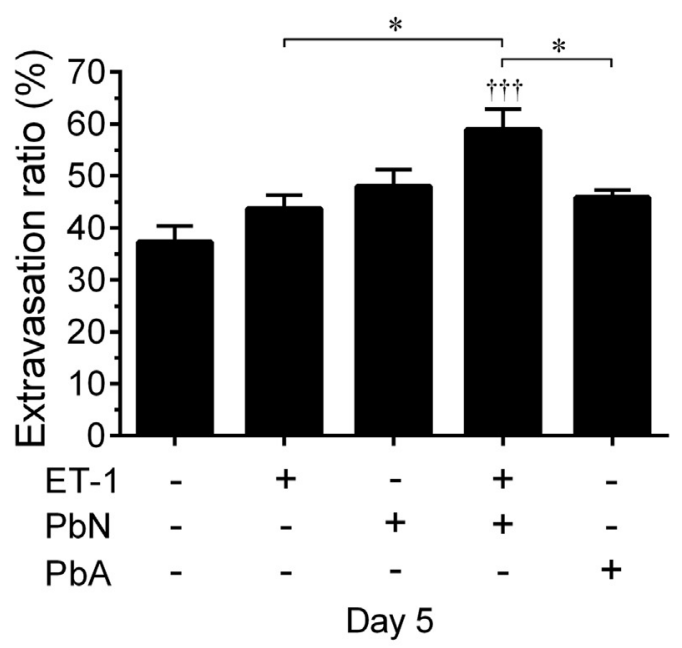

B

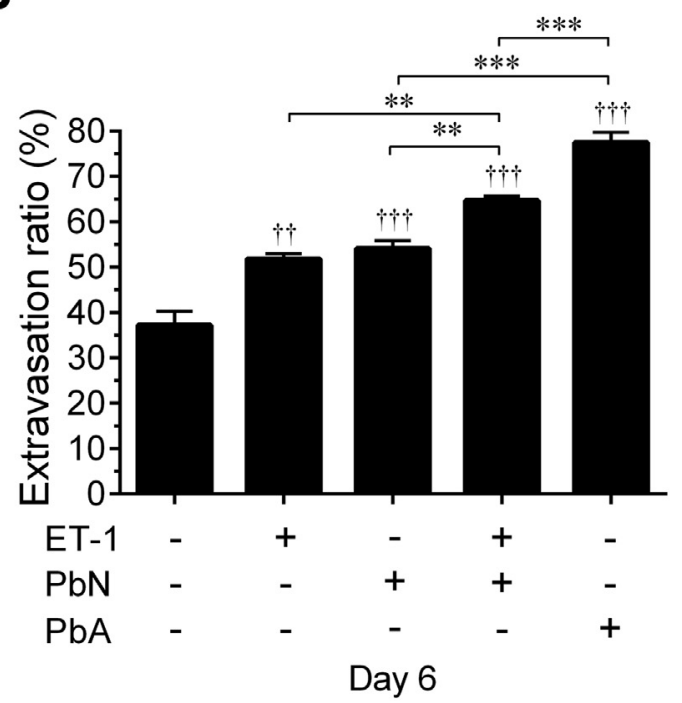

C

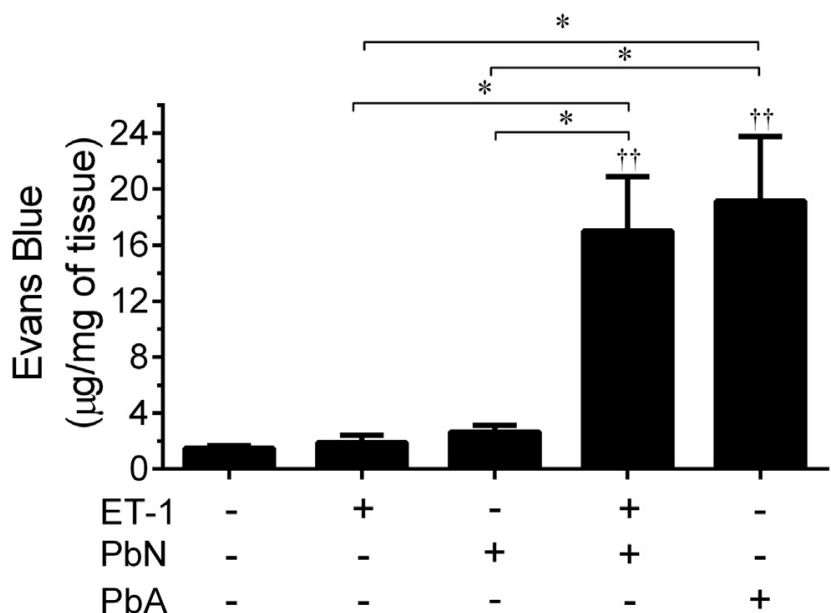

Day 6
$\mathrm{PbN}$-infected mice, similar to ECM. Although CXCL-8 is generally thought to be a neutrophil chemoattractant, the chemokine has been implicated in monocyte recruitment to the placenta during malaria infection in pregnancy. ${ }^{62}$ In addition, CSF CXCL-8 has been found to strongly correlate with cognitive impairment in pediatric $\mathrm{CM}^{37}$ Furthermore, CXCL-8 has been shown to induce strong adhesion of monocytes to vascular endothelia. ${ }^{63}$ Our data did not reveal any effect of exogenous ET-1 on the mRNA expression of CCL2 or of cellular adhesion molecules, although these mediators were significantly increased with $\mathrm{PbA}$ infection. In this study, we only evaluated message levels of these mediators at a single time point. These data demonstrate a need for future studies evaluating the kinetic expression of activated forms of those proteins, as it may be that ET-1 is involved in the translation or activation of these molecules. The data also suggest that multiple factors beyond ET-1 may be involved in the up-regulation of these mediators during $\mathrm{PbA}$ infection.

In this regard, Pamplona et al ${ }^{64}$ have demonstrated that administration of free heme, which is polymerized into hemozoin by the parasite, triggers an ECM-like syndrome in $\mathrm{C} 57 \mathrm{BL} / 6$ mice infected with $\mathrm{PbN}$. Hemozoin has been shown to activate the release of proinflammatory mediators by endothelial cells. ${ }^{65}$ Interestingly, it has also been demonstrated that $P$. falciparum-derived lipid moieties in the membrane of infected red blood cells and of hemozoin can trap ET- $1,{ }^{66}$ suggesting that there is cross talk between these processes in inducing the pathophysiology of CM.

Multiple plasmodial and host factors are likely responsible for the high levels of ET-1 found in human and experimental CM. ET-1 is synthesized by vascular endothelial cells throughout the body as well as by a variety of other cells, including leukocytes, fibroblasts, vascular smooth muscle cells, neurons, and astrocytes. ${ }^{25}$ Many of these cells are directly involved in the pathogenesis of cerebral malaria and

Figure 6 ET-1 disrupted blood-brain barrier (BBB) integrity in $\mathrm{PbN}$-infected mice. A and B: ET-1-treated PbN-infected mice had significantly greater leakage of fluorescein isothiocyanate (FITC) albumin than uninfected mice, using intravital microscopy quantification at 5 and 6 days postinfection (dpi). The degree of BBB leakage was significantly more than in $\mathrm{PbA}$-infected mice. B: At $6 \mathrm{dpi}$, all infected mice and uninfected mice treated with ET-1 had significantly more leakage of FITC albumin than uninfected mice given normal saline (NS). The leakage of FITC albumin was significantly greater in $\mathrm{PbN}$-infected mice treated with ET-1 than $\mathrm{PbN}$ infected mice given NS or uninfected mice treated with ET-1. PbA-infected mice had significantly more FITC albumin leakage than $\mathrm{PbN}$ mice, with or without ET-1 treatment. C: With Evans Blue Dye (EBD) bound albumin quantification, $\mathrm{PbA}$-infected and $\mathrm{PbN}+\mathrm{ET}-1$ mice had significant $\mathrm{BBB}$ disruption compared to uninfected mice given NS, whereas $\mathrm{PbN}$ mice and uninfected mice treated with ET-1 had similar levels of EBD leakage in the brain to uninfected mice given NS. The EBD leakage in PbA-infected and in ET-1-treated $\mathrm{PbN}$-infected mice was significantly greater than either $\mathrm{PbN}$ mice treated with NS or ET-1-treated uninfected mice. ${ }^{*} P<0.05$, ${ }^{* *} P<0.01$, and ${ }^{* * *} P<0.001$ when comparing groups; ${ }^{\dagger \dagger} P<0.01$, ${ }^{\dagger \dagger} P<0.001$ relative to baseline measurements. 
can be potential sources of increased ET-1 synthesis during infection. In addition, it is well known that activation of endothelial cells releases ET-1, ${ }^{67,68}$ and multiple factors, such as hypoxia, IL-1, tumor necrosis factor- $\alpha$, interferon- $\gamma$, certain Plasmodium falciparum erythrocyte membrane protein 1 subtypes, leukocyte activation, free heme release, and low nitric oxide bioavailability, have been implicated in the endothelial cell activation during human and ECM. ${ }^{2}$ As noted previously, the lipid moiety of hemozoin binds ET-1. ${ }^{66}$ This may further contribute to increased concentrations of ET-1 at sites of pRBC sequestration, as lysed RBCs have been shown to release ET-1 in response to certain stimuli. ${ }^{69}$ These reports suggest that there are complex and multiple redundant pathways involved in endothelial cell activation during uncomplicated and cerebral malaria, which could potentially increase ET-1 during malaria infection.

Overall, our findings support the notion that ET-1 plays a detrimental role in $\mathrm{CM}$. $\mathrm{PbN}$-infected mice displayed little to no brain pathology and no neurological impairments. However, ET-1 induced cerebrovascular pathology and corresponding neurological impairments in $\mathrm{PbN}$-infected mice. In this study, ET-1 protein levels were significantly higher in $\mathrm{PbN}$ mice treated with exogenous ET-1 and in $\mathrm{PbA}$-infected mice than in uninfected control mice and in $\mathrm{PbN}$-infected mice. Although the plasma half-life of ET-1 is 1 to 7 minutes, ${ }^{70}$ the effect on blood pressure after a lowdose bolus either by injection or continuous infusion (1 $\mathrm{nmol} / \mathrm{kg}$ in rats, $4 \mathrm{pmol} / \mathrm{kg}$ per minute in humans) lasted for $>1$ hour after exogenous administration. ${ }^{71,72}$ This is likely because of the fact that uptake of the peptide and into various tissues and its eventual dissociation from its cognate binding sites in those tissue is extremely slow (ie, $>30$ hours). ${ }^{73,74}$ Herein, we demonstrated that mice infected with $\mathrm{PbN}$ (non-ECM model) developed vascular alterations with corresponding neurological impairments, resulting in an ECM-like syndrome, when administered exogenous ET-1. These findings corroborate previous studies and further suggest that ET-1 contributes to the genesis of CM, by exacerbating cerebrovascular dysfunction. In a recent publication, we demonstrated that treatment of $\mathrm{PbA}$-infected mice with endothelin receptor A blockers preserved vascular integrity, prevented leukocyte infiltration, greatly mitigated long-term memory loss, and subsequently improved survival in mice with ECM. ${ }^{75}$ Microvascular alterations are a hallmark of $\mathrm{CM}$, yet there are currently no therapeutic strategies targeting these vascular complications in clinical settings. This study suggests that exploration of therapeutics aimed at targeting the ET-1 signaling cascade is warranted, as they may prevent both vascular and cognitive deficits in patients with $\mathrm{CM}$.

\section{Supplemental Data}

Supplemental material for this article can be found at http://dx.doi.org/10.1016/j.ajpath.2016.07.020.

\section{References}

1. Manning L, Laman M, Davis WA, Davis TM: Clinical features and outcome in children with severe Plasmodium falciparum malaria: a meta-analysis. PLoS One 2014, 9:e86737

2. Carvalho LJ, Moreira Ada S, Daniel-Ribeiro CT, Martins YC: Vascular dysfunction as a target for adjuvant therapy in cerebral malaria. Mem Inst Oswaldo Cruz 2014, 109:577-588

3. Desruisseaux MS, Machado FS, Weiss LM, Tanowitz HB, Golightly LM: Cerebral malaria: a vasculopathy. Am J Pathol 2010, 176:1075-1078

4. Pongponratn E, Riganti M, Punpoowong B, Aikawa M: Microvascular sequestration of parasitized erythrocytes in human falciparum malaria: a pathological study. Am J Trop Med Hyg 1991, 44:168-175

5. Medana IM, Day NP, Sachanonta N, Mai NT, Dondorp AM, Pongponratn E, Hien TT, White NJ, Turner GD: Coma in fatal adult human malaria is not caused by cerebral oedema. Malar J 2011, 10 : 267

6. Pongponratn E, Turner GD, Day NP, Phu NH, Simpson JA, Stepniewska K, Mai NT, Viriyavejakul P, Looareesuwan S, Hien TT, Ferguson DJ, White NJ: An ultrastructural study of the brain in fatal Plasmodium falciparum malaria. Am J Trop Med Hyg 2003, 69: 345-359

7. Carvalho LJ: Murine cerebral malaria: how far from human cerebral malaria? Trends Parasitol 2010, 26:271-272

8. White NJ, Turner GD, Medana IM, Dondorp AM, Day NP: The murine cerebral malaria phenomenon. Trends Parasitol 2010, 26:11-15

9. Stevenson MM, Gros P, Olivier M, Fortin A, Serghides L: Cerebral malaria: human versus mouse studies. Trends Parasitol 2010, 26: $274-275$

10. Riley EM, Couper KN, Helmby H, Hafalla JC, de Souza JB, Langhorne J, Jarra WB, Zavala F: Neuropathogenesis of human and murine malaria. Trends Parasitol 2010, 26:277-278

11. Martins YC, Carvalho LJ, Daniel-Ribeiro CT: Challenges in the determination of early predictors of cerebral malaria: lessons from the human disease and the experimental murine models. Neuroimmunomodulation 2009, 16:134-145

12. Cabrales P, Zanini GM, Meays D, Frangos JA, Carvalho LJ: Murine cerebral malaria is associated with a vasospasm-like microcirculatory dysfunction, and survival upon rescue treatment is markedly increased by nimodipine. Am J Pathol 2010, 176:1306-1315

13. Dai M, Freeman B, Bruno FP, Shikani HJ, Tanowitz HB, Weiss LM, Reznik SE, Stephani RA, Desruisseaux MS: The novel ETA receptor antagonist HJP-272 prevents cerebral microvascular hemorrhage in cerebral malaria and synergistically improves survival in combination with an artemisinin derivative. Life Sci 2012, 91:687-692

14. Machado FS, Desruisseaux MS, Nagajyothi, Kennan RP, Hetherington HP, Wittner M, Weiss LM, Lee SC, Scherer PE, Tsuji M, Tanowitz HB: Endothelin in a murine model of cerebral malaria. Exp Biol Med (Maywood) 2006, 231:1176-1181

15. Martins YC, Smith MJ, Pelajo-Machado M, Werneck GL, Lenzi HL, Daniel-Ribeiro CT, Carvalho LJ: Characterization of cerebral malaria in the outbred Swiss Webster mouse infected by Plasmodium berghei ANKA. Int J Exp Pathol 2009, 90:119-130

16. Clemmer L, Martins YC, Zanini GM, Frangos JA, Carvalho LJ: Artemether and artesunate show the highest efficacies in rescuing mice with late-stage cerebral malaria and rapidly decrease leukocyte accumulation in the brain. Antimicrob Agents Chemother 2011, 55: $1383-1390$

17. Nacer A, Movila A, Baer K, Mikolajczak SA, Kappe SH, Frevert U: Neuroimmunological blood brain barrier opening in experimental cerebral malaria. PLoS Pathog 2012, 8:e1002982

18. Ong PK, Melchior B, Martins YC, Hofer A, Orjuela-Sanchez P, Cabrales P, Zanini GM, Frangos JA, Carvalho LJ: Nitric oxide synthase dysfunction contributes to impaired cerebroarteriolar reactivity in experimental cerebral malaria. PLoS Pathog 2013, 9:e1003444 
19. Dai M, Freeman B, Shikani HJ, Bruno FP, Collado JE, Macias R, Reznik SE, Davies P, Spray DC, Tanowitz HB, Weiss LM, Desruisseaux MS: Altered regulation of Akt signaling with murine cerebral malaria, effects on long-term neuro-cognitive function, restoration with lithium treatment. PLoS One 2012, 7:e44117

20. Wenisch $\mathrm{C}$, Wenisch $\mathrm{H}$, Wilairatana $\mathrm{P}$, Looareesuwan $\mathrm{S}$, Vannaphan S, Wagner O, Graninger W, Schonthal E, Rumpold H: Big endothelin in patients with complicated Plasmodium falciparum malaria. J Infect Dis 1996, 173:1281-1284

21. Dietmann A, Lackner P, Helbok R, Spora K, Issifou S, Lell B, Reindl M, Kremsner PG, Schmutzhard E: Opposed circulating plasma levels of endothelin-1 and C-type natriuretic peptide in children with Plasmodium falciparum malaria. Malar J 2008, 7:253

22. Rubanyi GM, Polokoff MA: Endothelins: molecular biology, biochemistry, pharmacology, physiology, and pathophysiology. Pharmacol Rev 1994, 46:325-415

23. Kedzierski RM, Yanagisawa M: Endothelin system: the double-edged sword in health and disease. Annu Rev Pharmacol Toxicol 2001, 41: 851-876

24. Bagnato A, Loizidou M, Pflug BR, Curwen J, Growcott J: Role of the endothelin axis and its antagonists in the treatment of cancer. Br J Pharmacol 2011, 163:220-233

25. Vignon-Zellweger N, Heiden S, Miyauchi T, Emoto N: Endothelin and endothelin receptors in the renal and cardiovascular systems. Life Sci 2012, 91:490-500

26. Arai H, Hori S, Aramori I, Ohkubo H, Nakanishi S: Cloning and expression of a cDNA encoding an endothelin receptor. Nature 1990, 348:730-732

27. Sakurai T, Yanagisawa M, Takuwa Y, Miyazaki H, Kimura S, Goto K, Masaki T: Cloning of a cDNA encoding a non-isopeptide-selective subtype of the endothelin receptor. Nature 1990, 348:732-735

28. Committee for the Update of the Guide for the Care and Use of Laboratory Animals; National Research Council: Guide for the Care and Use of Laboratory Animals: Eighth Edition. Washington, DC, National Academies Press, 2011

29. Martins YC, Werneck GL, Carvalho LJ, Silva BP, Andrade BG, Souza TM, Souza DO, Daniel-Ribeiro CT: Algorithms to predict cerebral malaria in murine models using the SHIRPA protocol. Malar J 2010, 9:85

30. Dai M, Reznik SE, Spray DC, Weiss LM, Tanowitz HB, Gulinello M, Desruisseaux MS: Persistent cognitive and motor deficits after successful antimalarial treatment in murine cerebral malaria. Microbes Infect 2010, 12:1198-1207

31. Mostany R, Portera-Cailliau C: A craniotomy surgery procedure for chronic brain imaging. J Vis Exp 2008, 12:680

32. Mayhan WG, Heistad DD: Permeability of blood-brain barrier to various sized molecules. Am J Physiol 1985, 248:H712-H718

33. Fischer MJ, Uchida S, Messlinger K: Measurement of meningeal blood vessel diameter in vivo with a plug-in for ImageJ. Microvasc Res 2010, 80:258-266

34. Gaber MW, Yuan H, Killmar JT, Naimark MD, Kiani MF, Merchant TE: An intravital microscopy study of radiation-induced changes in permeability and leukocyte-endothelial cell interactions in the microvessels of the rat pia mater and cremaster muscle. Brain Res Brain Res Protoc 2004, 13:1-10

35. Dorovini-Zis K, Schmidt K, Huynh H, Fu W, Whitten RO, Milner D, Kamiza S, Molyneux M, Taylor TE: The neuropathology of fatal cerebral malaria in malawian children. Am J Pathol 2011, 178: $2146-2158$

36. Ponsford MJ, Medana IM, Prapansilp P, Hien TT, Lee SJ, Dondorp AM, Esiri MM, Day NP, White NJ, Turner GD: Sequestration and microvascular congestion are associated with coma in human cerebral malaria. J Infect Dis 2012, 205:663-67

37. John CC, Panoskaltsis-Mortari A, Opoka RO, Park GS, Orchard PJ, Jurek AM, Idro R, Byarugaba J, Boivin MJ: Cerebrospinal fluid cytokine levels and cognitive impairment in cerebral malaria. Am J Trop Med Hyg 2008, 78:198-205
38. Orjuela-Sanchez P, Ong PK, Zanini GM, Melchior B, Martins YC, Meays D, Frangos JA, Carvalho LJ: Transdermal glyceryl trinitrate as an effective adjunctive treatment with artemether for late-stage experimental cerebral malaria. Antimicrob Agents Chemother 2013, $57: 5462-5471$

39. Martins YC, Clemmer L, Orjuela-Sanchez P, Zanini GM, Ong PK, Frangos JA, Carvalho LJ: Slow and continuous delivery of a low dose of nimodipine improves survival and electrocardiogram parameters in rescue therapy of mice with experimental cerebral malaria. Malar J 2013, 12:138

40. Wagner OF, Christ G, Wojta J, Vierhapper H, Parzer S, Nowotny PJ, Schneider B, Waldhausl W, Binder BR: Polar secretion of endothelin-1 by cultured endothelial cells. J Biol Chem 1992, 267:16066-16068

41. Nolte D, Zeintl H, Steinbauer M, Pickelmann S, Messmer K: Functional capillary density: an indicator of tissue perfusion? Int J Microcirc Clin Exp 1995, 15:244-249

42. Bauer B, Hartz AM, Miller DS: Tumor necrosis factor alpha and endothelin-1 increase P-glycoprotein expression and transport activity at the blood-brain barrier. Mol Pharmacol 2007, 71:667-675

43. Leung JW, Chung SS, Chung SK: Endothelial endothelin-1 overexpression using receptor tyrosine kinase tie-1 promoter leads to more severe vascular permeability and blood brain barrier breakdown after transient middle cerebral artery occlusion. Brain Res 2009, 1266 : $121-129$

44. Yen LF, Wei VC, Kuo EY, Lai TW: Distinct patterns of cerebral extravasation by Evans blue and sodium fluorescein in rats. PLoS One 2013, 8:e68595

45. Bingaman S, Huxley VH, Rumbaut RE: Fluorescent dyes modify properties of proteins used in microvascular research. Microcirculation 2003, 10:221-231

46. Rumbaut RE, Harris NR, Sial AJ, Huxley VH, Granger DN: Leakage responses to 1-NAME differ with the fluorescent dye used to label albumin. Am J Physiol 1999, 276:H333-H339

47. Freeman BD, Machado FS, Tanowitz HB, Desruisseaux MS: Endothelin- 1 and its role in the pathogenesis of infectious diseases. Life Sci 2014, 118:110-119

48. McCarron RM, Wang L, Stanimirovic DB, Spatz M: Endothelin induction of adhesion molecule expression on human brain microvascular endothelial cells. Neurosci Lett 1993, 156:31-34

49. Stanimirovic DB, Bertrand N, McCarron R, Uematsu S, Spatz M: Arachidonic acid release and permeability changes induced by endothelins in human cerebromicrovascular endothelium. Acta Neurochir Suppl 1994, 60:71-75

50. Stanimirovic DB, McCarron R, Bertrand N, Spatz M: Endothelins release $51 \mathrm{Cr}$ from cultured human cerebromicrovascular endothelium. Biochem Biophys Res Commun 1993, 191:1-8

51. Patankar TF, Karnad DR, Shetty PG, Desai AP, Prasad SR: Adult cerebral malaria: prognostic importance of imaging findings and correlation with postmortem findings. Radiology 2002, 224:811-816

52. Mohanty S, Taylor TE, Kampondeni S, Potchen MJ, Panda P, Majhi M, Mishra SK, Wassmer SC: Magnetic resonance imaging during life: the key to unlock cerebral malaria pathogenesis? Malar J 2014, 13:276

53. Idro R, Jenkins NE, Newton CR: Pathogenesis, clinical features, and neurological outcome of cerebral malaria. Lancet Neurol 2005, 4: $827-840$

54. Chew BH, Weaver DF, Gross PM: Dose-related potent brain stimulation by the neuropeptide endothelin-1 after intraventricular administration in conscious rats. Pharmacol Biochem Behav 1995, 51: $37-47$

55. Nakajima M, Morimoto S, Takamoto S, Kitano S, Fukuo K, Onishi T, Ogihara T: Endothelin-1 in cerebrospinal fluid in elderly patients with hypertension and dementia. Hypertension 1994, 24:97-100

56. Palmer JC, Barker R, Kehoe PG, Love S: Endothelin-1 is elevated in Alzheimer's disease and upregulated by amyloid-beta. J Alzheimers Dis 2012, 29:853-861 
57. Briyal S, Philip T, Gulati A: Endothelin-A receptor antagonists prevent amyloid-beta-induced increase in ETA receptor expression, oxidative stress, and cognitive impairment. J Alzheimers Dis 2011, 23:491-503

58. Legos JJ, Lenhard SC, Haimbach RE, Schaeffer TR, Bentley RG, McVey MJ, Chandra S, Irving EA, Andrew AP, Barone FC: SB 234551 selective ET(A) receptor antagonism: perfusion/diffusion MRI used to define treatable stroke model, time to treatment and mechanism of protection. Exp Neurol 2008, 212:53-62

59. Reid JL, Dawson D, Macrae IM: Endothelin, cerebral ischaemia and infarction. Clin Exp Hypertens 1995, 17:399-407

60. Patel TR, Galbraith S, Graham DI, Hallak H, Doherty AM, McCulloch J: Endothelin receptor antagonist increases cerebral perfusion and reduces ischaemic damage in feline focal cerebral ischaemia. J Cereb Blood Flow Metab 1996, 16:950-958

61. Matsuo Y, Mihara S, Ninomiya M, Fujimoto M: Protective effect of endothelin type A receptor antagonist on brain edema and injury after transient middle cerebral artery occlusion in rats. Stroke 2001, 32: $2143-2148$

62. Abrams ET, Brown H, Chensue SW, Turner GD, Tadesse E, Lema VM, Molyneux ME, Rochford R, Meshnick SR, Rogerson SJ: Host response to malaria during pregnancy: placental monocyte recruitment is associated with elevated beta chemokine expression. J Immunol 2003, 170:2759-2764

63. Gerszten RE, Garcia-Zepeda EA, Lim YC, Yoshida M, Ding HA, Gimbrone MA Jr, Luster AD, Luscinskas FW, Rosenzweig A: MCP1 and IL-8 trigger firm adhesion of monocytes to vascular endothelium under flow conditions. Nature 1999, 398:718-723

64. Pamplona A, Ferreira A, Balla J, Jeney V, Balla G, Epiphanio S, Chora A, Rodrigues CD, Gregoire IP, Cunha-Rodrigues M, Portugal S, Soares MP, Mota MM: Heme oxygenase-1 and carbon monoxide suppress the pathogenesis of experimental cerebral malaria. Nat Med 2007, 13:703-710

65. Griffith JW, Sun T, McIntosh MT, Bucala R: Pure Hemozoin is inflammatory in vivo and activates the NALP3 inflammasome via release of uric acid. J Immunol 2009, 183:5208-5220
66. Basilico N, Parapini S, Sisto F, Omodeo-Sale F, Coghi P, Ravagnani F, Olliaro P, Taramelli D: The lipid moiety of haemozoin (malaria pigment) and $\mathrm{P}$. falciparum parasitised red blood cells bind synthetic and native endothelin-1. J Biomed Biotechnol 2010, 2010:854927

67. Basilico N, Mondani M, Parapini S, Speciale L, Ferrante P, Taramelli D: Plasmodium falciparum parasitized red blood cells modulate the production of endothelin-1 by human endothelial cells. Minerva Med 2004, 95:153-158

68. Kuchan MJ, Frangos JA: Shear stress regulates endothelin-1 release via protein kinase $\mathrm{C}$ and cGMP in cultured endothelial cells. Am J Physiol 1993, 264:H150-H156

69. Tippler B, Herbst C, Simmet T: Evidence for the formation of endothelin by lysed red blood cells from endogenous precursor. Eur J Pharmacol 1994, 271:131-139

70. Sirvio ML, Metsarinne K, Saijonmaa O, Fyhrquist F: Tissue distribution and half-life of 125I-endothelin in the rat: importance of pulmonary clearance. Biochem Biophys Res Commun 1990, 167: 1191-1195

71. Shiba R, Yanagisawa M, Miyauchi T, Ishii Y, Kimura S, Uchiyama Y, Masaki T, Goto K: Elimination of intravenously injected endothelin-1 from the circulation of the rat. J Cardiovasc Pharmacol 1989, 13 Suppl 5:S98-S101; discussion S2

72. Weitzberg E, Ahlborg G, Lundberg JM: Differences in vascular effects and removal of endothelin-1 in human lung, brain, and skeletal muscle. Clin Physiol 1993, 13:653-662

73. Waggoner WG, Genova SL, Rash VA: Kinetic analyses demonstrate that the equilibrium assumption does not apply to [125I]endothelin-1 binding data. Life Sci 1992, 51:1869-1876

74. Parker JD, Thiessen JJ, Reilly R, Tong JH, Stewart DJ, Pandey AS: Human endothelin-1 clearance kinetics revealed by a radiotracer technique. J Pharmacol Exp Ther 1999, 289:261-265

75. Freeman BD, Martins YC, Akide-Ndunge OB, Bruno FP, Wang H, Tanowitz HB, Spray DC, Desruisseaux MS: Endothelin-1 mediates brain microvascular dysfunction leading to long-term cognitive impairment in a model of experimental cerebral malaria. PLoS Pathog 2016, 12:e1005477 